\title{
KONSTRUKSI SANKSI ADMINISTRATIF PERATURAN DAERAH PROVINSI BALI NOMOR 2 TAHUN 2012
}

\author{
Oleh: \\ Kadek Putra Arik Persona ${ }^{1}$
}

\begin{abstract}
The study describes the overlap of arrangements of administrative sanctions in the Law No. 12 of 2011 with the construction of administrative sanctions in the Local Regulation of Bali Province No. 2 of 2012. The arrangements of administrative sanctions according to Law No. 12 of 2011 are stipulated in appendix II number 64 which stipulates that the substance in the form of administrative sanctions or civil sanctions for the violation of these norms are formulated into one part (chapter) with the norms that impose administrative sanctions or civil sanctions, and in appendix II number 65 which regulates if there is more than one norm that provides administrative or civil sanctions, administrative sanctions or civil sanctions are formulated in the last chapter of the section. Thus, it does not formulate the provision of sanctions that also contains criminal sanctions, civil penalties and administrative sanctions in one chapter. The arrangements of administrative sanctions in the Local Regulation of Bali Province No. 2 of 2012 are stipulated in Chapter XIV of Article 33 paragraph (1), (2), and (3), thus it is contrary to the provisions of Appendix II of Law of the Republic of Indonesia Number 12 of 2011 numbers 64 and 65.
\end{abstract}

Keywords: Administrative Sanctions, Local Regulation, Tourism

\section{PENDAHULUAN}

\subsection{Latar Belakang}

Teknologi informasi memberikan pengaruh yang besar kepada setiap orang untuk melakukan perjalanan wisata ke berbagai tempat di dunia. Setiap orang berhak untuk melakukan perjalanan ke daerah lain baik dalam satu negara maupun ke negara lain. Berbagai macam motifasi yang menyebabkan seseorang melakukan perjalanan antara lain adalah untuk bekerja, berwisata, sekolah, tugas Negara, dan lainnya. Melakukan perjalanan ke luar wilayah atau melepaskan diri dari aktifitas sehari-hari dengan tujuan mencari

Mahasiswa Magister Ilmu Hukum Universitas Udayana, Denpasar, Bali. Alamat Jl. Sudamala Gang I Nomor 24 Semawang Sanur, e-mail: arik_persona@ yahoo.com kesenangan dan kenyamanan merupakan salah satu tujuan hidup dari seseorang. Setiap orang akan berusaha untuk meluangkan waktu dan menyisihkan sebagian kecil dari penghasilannya untuk dapat melakukan perjalanan wisata dalam setiap tahunnya. Klasifikasi wisata terdiri dari beberapa jenis antara lain hiburan, spiritual, alam, budaya, makanan, dan berbagai macam lainnya yang semakin hari semakin berkembang. Bali memiliki ciri tersendiri dalam dunia wisata yaitu mengedepankan budaya sebagai ujung tombak daya tarik penikmat wisata sehingga mampu menghasilkan pendapatan negara yang berguna untuk mensejahterakan masyarakat. Budaya dan agama di bali merupakan dua hal yang tidak dapat dipisahkan. Banyak ritual budaya dalam melaksanakan upacara agama yang mampu 
menarik orang untuk datang ke pulau yang terkenal dengan sebutan pulau seribu pura.

Tingkat kejenuhan manusia dewasa ini menciptakan peluang yang sangat menguntungkan terhadap perkembangan aspek pariwisata. Perkembangan pariwisata dewasa ini memberikan peluang bagi pertumbuhan ekonomi di Indonesia. Investasi di industri kepariwisataan mengalami pertumbuhanyangsangatpesat.Pembentukan karakter pembangunan pariwisata harus dijalankan secara berkelanjutan. ${ }^{2}$ Hal -hal yang menjadi prioritas untuk diperhatikan dalam menciptakan pariwisata yang baik adalah terjaganya sumber daya alam, tingkat kesadaran pelaku dalam dunia wisata, keamanan, koordinasi yang solid antara instansi yang terkait, dan kecakapan dan keterampilan dalam merumuskan sebuah kebijakan kepariwisataan yang memenuhi kebutuhan generasi saat ini tanpa harus merusak, menghilangkan, dan mengurangi pemenuhan kebutuhan generasi yang akan datang. Pariwisata yang baik akan tercipta jika diatur dengan baik. Konteks kata atur yang dimaksud diawali sejak pembentukan aturan, dapat dilaksanakannya, dan adanya sistem peradilan yang baik terhadap pelanggarannya.Investormemilikikewajiban yang harus ditaati dalam menjalan usaha di sektor pariwisata. Kewajiban-kewajiban yang harus ditaati oleh investor diatur dalam peraturan perundang-undangan. Kaidah yang baik akan menciptakan tatanan kehidupan masyarakat yang tertib. Jika masyarakat sudah tertib maka secara otomatis keamanan akan terjaga. Keamanan merupakan salah satu unsur yang sangat penting dalam penerapan

Made Metu Dahana, 2012, Perlindungan Hukum dan Keamanan Terhadap Wisatawan, Paramita, Surabaya, hlm.1. kegiatan wisata di Bali. Upaya menciptakan keadaan yang harmonis diawali dengan menciptakan tatanan norma yang baik. Dari sudut pandang penyusunan sebuah norma merupakan kewenangan yang dimiliki oleh pemerintah daerah dan DPRD. Kerjasama yang baiksangat dituntut dalammenghasilkan pengaturan yang melindungi kepentingan warga secara absolut. Kewenangan untuk membentuk sebuah tatanan norma di Indonesia merupakan kompetensi dari pihak eksekutif dan legislatif. Berbeda halnya dengan trias politica yang menganut paham pemisahan kekuasaan secara mutlak sehingga dalam menyusun, merancang sebuah aturan merupakan murni wewenang dari pejabat legislatif, sedangkan pihak pemerintah secara penuh hanya dalam batas melaksanakannya. Provinsi Bali memiliki regulasi terkait dengan kepariwisataan budaya Bali. Kepariwisataan budaya Bali diatur dalam Perda Nomor 2 Tahun 2012. Hal-hal yang diatur adalah mengenai kumpulan kaidah yang membebankan kewajiban terhadap penyelenggara dan wisatawan. Sebagai wujud penerapan negara hukum, aturan yang telah ditetapkan tidak membedakan perlakukan antara wisatawan dari dalam negeri dan wisatawan dari luar negara republik Indonesia. Disusunnya kewajiban dan hak dalam sebuah aturan yang bersifat lokal merupakan pencerminan dari sistem negara berdasar atas hukum yang menentukan bahwa pemerintahan dilaksanakan berdasarkan ketentuan undangundang. Kewajiban yang harus ditaati oleh pengusaha pariwisata di dalam Pasal 27. Setiap pengusaha pariwisata yang melangar ketentuan Pasal 27 Peraturan Daerah Bali Nomor 12 Tahun 2012 dikenakan sanksi administratif yang diatur dalam Bab XIV 
Pasal 33. Pengaturan sanksi administratif dalam Peraturan daerah Bali Nomor 2 Tahun 2012 bertentangan dengan ketentuan Pengaturan sanksi administratif dalam lampiran II Undang-Undang Nomor 12 Tahun 2011 tentang Pembentukan Peraturan Perundang-undangan.

\subsection{Rumusan Masalah}

Berdasarkan uraian latar belakang diatas, maka penulis merumuskan permasalahan sebagai berikut :

1. Bagaimanakah pengaturan sanksi administratifmenurut Undang-Undang Nomor 12 Tahun 2011 ?

2. Bagaimanakah konstruksi pengaturan sanksi administratif Peraturan Daerah Bali Nomor 2 Tahun 2012 ?

\subsection{Tujuan Penelitian}

penelitian ini secara umum bertujuan untuk mengetahui konstruksi Peraturan Daerah Kepariwisataan Bali. Sedangkan yang menjadi tujuan khusus adalah :

1. Untuk mengetahui pengaturan sanksi administratifmenurut Undang-Undang Nomor 12 Tahun 2011.

2 Untuk mengetahui konstruksi pengaturan sanksi administratif Peraturan Daerah Bali Nomor 2 Tahun 2012.

\section{Metode Penelitian}

Jenis penelitian hukum normatif yang mengacu pada adanya konflik norma antara Undang-Undang Pembentukan Peraturan Perundang-undangan dengan dengan Peraturan Daerah Kepariwisataan Budaya Bali terkait dengan konstruksi sanksi administratif. Jenis pendekatan yang digunakan pada penulisan karya tulis ilmiah ini adalah pendekatan perundang-undangan, konsep, dan sistematis. Kajian perundangundangan sangat penting karena merupakan dasar pijakan dalam meneliti dan isu sebuah masalah. ${ }^{3}$

\section{Hasil dan Pembahasan}

\subsection{Perancangan sanksi administratif} Sebagaimana yang dikutip oleh Profesor Dr. A. Hamid Attamini dari Burkhard Krem menyatakan bahwa ilmu pengetahuan tentang Perundang-undangan terklasifikasi ke dalam dua bagian yaitu teori Perundang-undangan dan ilmu perundangundangan. ${ }^{4}$

Segalakegiatandalampenyelenggaraan Negara harus berdasarkan atas Hukum yang berlaku. Penyelenggaraan pemerintahan berdasarkan atas Hukum dengan tujuan menciptakan keadilan dan melindungi hak hak rakyat. Hukum akan melindungi hak-hak rakyat dan mampu mengendalikan pejabat negara dalam melaksanakan tugasnya. Penyelenggaraan pemerintahan akan berjalan dengan baik apabila ada aturan Hukum yang mengaturnya. Penyelenggaran pemerintahan yang berdasarkan atas Hukum akan menciptakan suatu keadaan yang tenteram, adil, dan sejahtera. Keadaan yang tenteram, adil, dan sejahtera dapat diwujudkan karena telah dijaminya perlindungan terhadap hakhak asasi manusia. Sah atau tidaknya tindakan pemerintah bertitik tolak pada undangundang. Pemerintah dalam melakukan tindakan hukum tidak diperkenankan diluar ketentuan yang telah ditentukan. Wewenang

Johnny Ibrahim, 2012, Teori dan Metode Penelitian Hukum Normatif Edisi Revisi, Bayumedia Publishing, Malang, hlm.302.

H. Aziz Syamsuddin, 2013, Proses dan Teknik Penyusunan Undang-Undang, Sinar Grafika, Jakarta, hlm.18. 
pemerintah lahir dari tiga hal anatara lain adalah berdasarkan perintah langsung dari undang-undang, pelimpahan wewenang, dan mandat. Pembuatan hukum merupakan salah satu peran fungsi legislatif. Konteks negara hukum menyatakan adanya pembagian kekuasaan yang terdiri dari pembentuk aturan, pelaksanana, dan penegak hukum. unsur yang pertama merupakan unsur yang sangat penting karena akan menentukan ketertiban umum dalam sebuah negara. Tiga hal yang harus mendapat perhatian lebih dari penyusun aturan adalah mengupayakan agar semaksimal mungkin terhindar dari tumpang tindih pengaturan, kekosongan hukum, dan pengaturan yang kabur. Aturan hukum yang multitafsir dapat menciptakan kekuasaan pemerintahan represif yang menyebabkan tidak diperhatikannya kepentingan orangorang yang diperintah. ${ }^{5}$ Tumpang tindih pengaturan dapat terjadi secara vertikal dan horizontal. Aturan yang tidak selaras secara langsung mengakibatkan terjadinya konflik kewenangan. Sebagai contoh pembentukan peraturan daerah merupakan kewenangan pemerintah daerah, namun di sisi lain terdapat ketentuan yang mengatur bahwa pemda dapat melibatkan instansi vertikal dalam pembentukannya. Kata dapat merupakan kata yang tidak memiliki kepastian hukum karena memiliki arti untuk tidak mewajibkan. Pejabat fungsional perancang yang memiliki legalitas hanya terdapat di instansi Kemenkumham. tenaga perancang tersebut telah mengikuti pendidikan dan pelatihan secara profesional dan memiliki kompetensi yang sangat baik.

Philipe Nonet and Philip Selznick, 1978, and Society in Transition: Toward Responsive Law, Harper Cholopon Books, New York, Hagerstown, San Fransisco, London, hlm.29.
Karena pengaturan yang tidak jelas maka kewenangan tim perancang hukum dan ham di daerah tidak dapat memaksakan diri untuk ikut terlibat di setiap pemkab atau pemprov.

Sumber daya manusia yang tidak memiliki keahlian dan kemampuan dalam menyusun sebuah draft aturan akan menciptakan aturan yang sangat tidak baik. Konflik kepentingan harus dihindari jika ingin menciptakan sebuah rule yang mampu mengakomodir kebutuhan masyarakat. Tahap perencanaan dilaksanakan dengan penyusunan naskah akademis. Dalam tahap ini akan menampilkan urgensi sebuah aturan.

Penyusunan peraturan daerah harus sesuai dengan materi muatan yang telah memiliki legalitas. Materi muatan sebuah peraturan adalah refleksi dari nilai kepastian, keadilan dan kemanfaatan. Perhatian khusus yang wajib diperhatikan adalah terpenuhinya syarat formal dan syarat material agar tidak terbentuk aturan yang cacat hukum. aturan yang cacat dapat terjadi jika legal drafter tidak mengindahkan acuan yang telah ditentukan.

Dasar pengenaan sanksi secara umum dibagi menjadi tiga jenis yaitu sanksi pidana, sanksi perdata dan sanksi administrasi. Jenis jenis sanksi administratif pada umumnya terdiri atas pencabutan ijin, penarikan keputusan dan adanya denda. Pengaturan sanksi administratif menurut UndangUndang Nomor 12 Tahun 2011 diatur dalam lampiran II Undang-Undang Republik Indonesia nomor 12 tahun 2011 angka 64 dan angka 65. Sanksi administratif dalam perancangan peraturan daerah tidak boleh diatur dalam bab tersendiri. Ketentuan hal tersebut diatur setelah frasa atau pasal yang memberikan larangan. Aturan yang baik 
adalah aturan yang sesuai dengan ketentuan perancangan perundang-undangan.

\subsection{Konstruksi Pengaturan Sanksi Administratif Peraturan Daerah Bali Nomor 2 Tahun 2012}

Peraturan perundang-undangan yang dibuat merupakan aturan tertulis yang dibuat oleh pejabat negara yang berwenang dan mengandung sanksi yang tegas terhadap seseorang yang melanggar ketentuan aturan tersebut. Aturan yang baik adalah peraturan yang tidak multitafsir dan responsif.

Membentuksuatuperaturanperundangundangan harus memiliki tujuan yang jelas. Aturan yang dibentuk harus mampu menciptakan rasa adil bagi seluruh rakyat dan tidak terjadi diskriminasi terhadap kaum atau golongan tertentu. Secara garis besar dalam pembentukan peraturan perundangundangan harus bersifat responsif yang mengandung artibahwa peraturan perundangundangan tersebut memang dibutuhkan oleh masyarakat. Agar suatu peraturan perundangundangan memiliki kekuatan mengikat maka peraturan perundang-undangan harus dibentuk oleh lembaga negara. Pada umumnya kewenangan lembaga negara dalam membentuk peraturan perundangundangan diatur dalam konsntitusi Negara tersebut.

Hukum tidak menggunakan persyaratan untuk mengikat manusia melalui kesadaran sehingga dapat juga dipandang berasal dari keinginan pemegang kekuasaan tertinggi, yaitu yang hanya memiliki hak dan tidak memiliki kewajiban, atau berasal dari kehendak sang pencipta. ${ }^{6}$ Undang-undang

E. Sumaryono, 2002, Etika Hukum, Kanisius, Yogyakarta, hlm.201. dapat dibagi dalam dua tingkatan, yaitu Undang-Undang dalam tingkatan yang lebih tinggi dan Undang-Undang dalam tingkatan yang lebih rendah. Secara hierarki, susunan dan tingkatan undang-undang adalah dimulai dari ketentuan yang lebih tinggi baru secara berturut-turut disusul dengan tingkatan undang-undang yang lebih rendah. ${ }^{7}$ Undangundang yang bermartabat lebih tinggi dari undang-undang biasa disebut Undangundang Dasar (UUD) yang di dalam bahasa belanda disebut grondwet. ${ }^{8}$

Peraturan hukum di Indonesia disusun secara sistematis sehingga tidak dapat ditafsirkan secara sendiri. ${ }^{9}$ Undang-Undang yang bermartabat lebih tinggi dari UndangUndang biasa disebut Undang-undang Dasar (UUD) yang di dalam bahasa belanda disebut grondwet. ${ }^{10}$

Manfaat suatu kaidah merupakan sifat sosiologis yang memaparkan mengenai desakan kebutuhan masyarakat sesuai dengan kenyataan yang berkembang. ${ }^{11}$ Sebuah tatanan aturan bersifat umum yang berarti bahwa tidak diperuntukan menganalisa secara perorangan sehingga memiliki daya mengikat secara luas. ${ }^{12}$

Kewenangan badan hukum membuat aturan merupakan sumber legalitas dari sebuah kaidah hukum ${ }^{13}$ Secara sistematis

Chainur Arrasjid, 2006, Dasar Dasar Ilmu Hukum, Sinar Grafika, Jakarta, hlm.54.

8 Hilman Hadikusuma, 2010, Bahasa Hukum Indonesia, PT Alumni, Bandung, hlm.45.

Yudha Bhakti Ardhiwisastra, Op. Cit, hlm.10.

10 Hilman Hadikusuma, Op. Cit, hlm.45.

11 Jimly Asshiddiqie, 2011, Perihal Undang-undang, PT Raja Grafindo Persada, Jakarta, hlm.118.

12 Yuliandri, 2013, Asas-Asas Pembentukan Peraturan Perundang-Undangan Yang Baik Gagasan Pembentukan Undang-Undang Berkelanjutan, PT Raja Grafindo Persada, Jakarta, hlm.25.

13 Bambang Sutiyoso, 2006, Metode Penemuan Hukum Upaya Mewujudkan Hukum Yang Pasti dan Berkeadilan, UII Press, Yogyakarta, hlm.43. 
perlu mengindah nilai-nilai perjenjangan norma agar tidak terjadi benturan regulasi. Aturan yang menjadi dasar adalah aturan yang bersifat abstrak yang memaparkan mengapa perlunya pengaturan atau hukum yang dicita-citakan kemudian dilimpah ke pengaturan yang sifatnya lebih nyata ke aturan yang sifatnya dapat dilaksanakan. Aturan konkrit bersumber pada spirit aturan yang abstrak. Semangat pengaturan khusus merupakan hasil pengalihan tanggung jawab aturan diatasnya. Sebuah aturan tidak akan bermanfaat jika tidak memiliki sanksi. Dimasukannya sebuah hukuman merupakan upaya pencegahan agar masyarakat tidak berani melakukan pelanggaran. Niat dari penyusun aturan dalam memasukan sebuah sanksi dapat dikatakan merupakan tindakan bersifat prevenmtif, namun penghukuman dari aparat merupakan tindakan represif. Penyusun aturan wajib memiliki moral, mental dan pemahaman spiritual yang baik agar tidak melahirkan produk hukum yang berbahaya bagi kalangan masyarakat banyak. Hukum adalah sesuatu hal yang dianggap benar oleh sebagian besar masyarakat.

Konstruksi Peraturan Perundanganundangan di Indonesia terkait dengan pengaturan sanksi administratif dalam pembentukan Peraturan Daerah Bali Nomor 2 Tahun 2012 dapat dikaji menggunakan pendekatan penafsiran Peraturan Perundangundangan secara sistematis dengan melakukan analisa dengan mengacu kepada Undang-Undang Nomor 12 Tahun 2012 tentang Pembentukan Peraturan Perundangundangan.

Konstruksi pengaturan sanksi administratif dalam pembentukan Peraturan Daerah harus sesuai dengan ketentuan dalam Lampiran II Undang-Undang RI nomor
12/2011 angka 64 yang mengatur bahwa materi tentang sanksi administratif diatur dalam satu bagian pasal yang melarangnya dan tidak dibuat dalam bab tersendiri. Sanksi administratif yang diatur dalam Peraturan Daerah Provinsi Bali Nomor 2 Tahun 2012 tidak sesuai dengan ketentuan yang telah diatur dalam Lampiran ke II Undang-Undang 12 tahun 2011 butir 64.

Konstruksi sanksi administratif yang diatur dalam Peraturan Daerah Nomor 2 Tahun 2012 Prov. Bali juga wajib mengacu pada bagian lampiran 2 butir 65. Pengaturan sanksi administratif dalam Peraturan Daerah Bali Nomor 2 Tahun 2012 diatur dalam bab xiv Pasal 33 ayat (1), (2), dan (3), sehingga bertentangan dengan ketentuan dalam Lampiran II Undang-Undang Republik Indonesia nomor 12 tahun 2011 angka 64, dan angka 65 . Ketentuan pengaturan dari sebuah peraturan yang lebih rendah tidak boleh bertentangan dengan ketentuan pengaturan dari aturan yang lebih tingi. Peraturan daerah tidak boleh bertentangan dengan UndangUndang, karena menurut hirarki peraturan perundang-undangan kedudukan Peraturan Daerah lebih rendah dari undang-undang.

\section{Simpulan dan Saran}

\subsection{Simpulan}

1. Pengaturan sanksi administratif menurut Undang-Undang Nomor 12 Tahun 2011 diatur dalam lampiran II angka 64 dan angka 65.

2. Pengaturan sanksi administratif dalam Peraturan Daerah Bali Nomor 2 Tahun 2012 diatur dalam Bab XIV tentang Pasal 33 ayat (1), (2), dan (3), dan tidak diatur setelah ketentuan yang memberikan larangan. 
4.2 Saran

1. Pengaturan sanksi administratif dalam Undang-Undang Pembentukan Peraturan Perundang-undangan Tahun 2011 merupakan acuan bagi peraturan daerah tingkat I Bali dalam mengkonstruksi sanksi administratif.

2. Ketentuan pengaturan sanksi administratif dalam Perda Provinsi Bali tentang kepariwisataan harus sesuai dengan ketentuan pengaturan saksi administratif pada lampiran II angka 64 dan angka 65 UndangUndang Nomor 12 Tahun 2011.

\section{DAFTAR PUSTAKA}

Bambang Sutiyoso, 2006, Metode Penemuan Hukum Upaya Mewujudkan Hukum Yang Pasti dan Berkeadilan, UII Press , Yogyakarta.

Chainur Arrasjid, 2006, Dasar Dasar Ilmu Hukum, Sinar Grafika, Jakarta.

E. Sumaryono, 2002, Etika Hukum, Kanisius, Yogyakarta.

H. Aziz Syamsuddin, 2013, Proses dan Teknik Penyusunan Undang-Undang, Sinar Grafika, Jakarta.

Hilman Hadikusuma, 2010, Bahasa Hukum Indonesia, PT Alumni, Bandung.

Jimly Asshiddiqie, 2011, Perihal Undangundang, PT Raja Grafindo Persada, Jakarta

Johnny Ibrahim, 2012, Teori dan Metode Penelitian Hukum Normatif Edisi Revisi, Bayumedia Publishing, Malang.

Philipe Nonet and Philip Selznick, 1978, and Society in Transition: Toward Responsive Law, Harper Cholopon Books, New York, Hagerstown, San Fransisco, London.
Yudha Bhakti Ardhiwisastra, 2008, Penafsiran dan Konstruksi Hukum, PT Alumni, Bandung.

Yuliandri, 2013, Asas-Asas Pembentukan Peraturan Perundang-Undangan Yang Baik Gagasan Pembentukan Undang-undang Berkelanjutan, PT Raja Grafindo Persada, Jakarta. 